\title{
Half-brother with Father as Common Parent
}

National Cancer Institute

\section{Source}

National Cancer Institute. Half-brother with Father as Common Parent. NCI Thesaurus. Code $C 96655$.

A male sibling who shares the genetic makeup inherited from only the biological father. 